\title{
"I haven't had the fun that is portrayed": First-year student expectations and experiences of starting at university
}

\section{Moeniera Moosa}

School of Education, University of the Witwatersrand, Johannesburg, South Africa moeniera.moosa@wits.ac.za https://orcid.org/0000-0002-6231-9370

\section{Dale Langsford}

School of Education, University of the Witwatersrand, Johannesburg, South Africa dale.langsford@wits.ac.za https://orcid.org/0000-0002-9142-5754

(Received: 8 September 2020; accepted: 6 April 2021)

\section{Abstract}

Prospective students have both expectations and anxieties about what their imminent university experiences might entail. In this study, we compare first-year students' expectations with their experiences of being included and excluded while settling into university life. Our participants in this qualitative phenomenological research study were 322 first-year students. We use insights from social and pedagogic inclusion to critique Tinto's (1983) model of the transition of students from schooling to higher education settings. The findings indicate that participants experienced mastery of knowledge, procedures, and structures of the institution as a point of exclusion almost $8 \%$ more than they expected. The participants also experienced personal disposition and relationships to be a point of exclusion $24 \%$ less than they expected. We recommend that university orientation programmes place more focus on the academic expectations of university since this was an aspect on which participants did not focus much. In addition, these findings also have implications for how universities conceptualise and implement the move to online learning which is often viewed as the solution to increasing access to higher education.

Keywords: first-year students, inclusion, transmission into higher education, social interactions 


\section{Introduction}

Being accepted to study at a university is an exciting moment for those South African learners who meet the admission requirements. It is the moment when they receive recognition for their hard work at school and the support of their parents and teachers. Institutions make calls for "bright and hardworking [students who] want to get ahead in life" (University of the Witwatersrand, 2020, n.p.) to apply to study towards an undergraduate qualification. Many South African first-year students also carry the pride of being firstgeneration university students (Vincent \& Hlatswayo, 2018). They look forward to experiencing university life and all the perceived benefits associated with having a university qualification. Additionally, amidst all the euphoria of going to university the transition is also often a period of "uncertainty and volatility" (Dias \& Sá, 2014, p. 300).

Much research has been done internationally and locally on the academic challenges of and support required by first-year students to succeed at university. The challenges are multicausal in nature and can be linked to personal circumstances and problems, funding concerns, inappropriate course selection, being unable to form social networks, and inadequate preuniversity education (Araque et al., 2009; Letseka et al., 2010; Ramrathan, 2013). These challenges highlight the importance of the academic and social integration of students that might enable their academic success at university (Tinto, 1983). To support students' transition into institutions of higher learning, their expectations, perceptions, and experiences of feeling included and excluded provide insights into the challenges they face. In this paper, we analyse the expectations of a group of first-year students on entry into higher education and compare them with the experiences that made them feel included and/or excluded within the first six weeks of their tertiary studies.

\section{Context of the study}

South African universities have become spaces in which students from diverse contexts converge to gain "epistemological access" (Morrow, 1992, p. 2) to specialised knowledge and to the skills required in academic and professional fields of study. Epistemological access refers to the acquisition of knowledge and skills through formal learning. In contrast, what is known as formal access is physical admission into the institution. Despite various orientation programmes on offer, students may not necessarily experience these programmes in the same way because of their diverse educational and socio-economic backgrounds. There must be a synergy between university structures and student agency (Case et al., 2018) for all students to succeed in higher education in South Africa. Consequently, the first few weeks at university can be a period during which students may feel included and/or excluded in various ways. The first semester at university is usually considered a transitional stage in which students are expected to adapt to the new environment at the university as well as cope with the additional pressures (Bean \& Eaton, 2000) of higher education. If students can acclimatise to the new environment, they are more likely to experience a sense of being included in it. 


\section{Transition from school to university: A stage model}

The ease of the transition from high school to university is contingent on a complex interaction of factors within a student's educational and socio-economic background (e.g., Camelia \& Nastase, 2018; Dison et al., 2019; Ramrathran, 2013), as well as challenges and support that the higher education institution offers to its incoming students (e.g., Jones et al., 2008; Underhill \& McDonald, 2010). Tinto (1983) provided an influential model to explain student's experiences of transitioning from high school to university that has been used widely as a basis for understanding first-year students' expectations compared with their experiences at university. To adjust to the university context, students move through various phases: separation; transition; and incorporation (Tinto, 1983). Each phase encompasses factors that provide an understanding of why students may be at risk of dropping out of university as Kwai (2009) has pointed out. In the context of the South African higher education sector, we note that Tinto (1983) promotes an assimilation model in terms of which diverse students are expected to adjust to an inclusive higher education institution. The calls for free, quality, decolonised education by students who participated in the \#FeesMustFall ${ }^{1}$ movement highlighted the fact that universities are not always inclusive spaces and need to be more responsive to the lived realities of their student bodies. We therefore engage in a review and critical discussion of Tinto's model of transition.

\section{Separation phase}

The separation phase is characterised by a decline in interactions with past associates and a change in behaviour. According to Tinto (1983) this is the phase during which first-year students need to dissociate themselves from their past school experiences and transition to a tertiary setting by becoming familiar with its norms and patterns. We agree that it is important for students to make mental and physical breaks from their previous learning context to integrate fully into a new context and adjust to their role, with its expectations, of being university students. Yet we note, with concern, that the dominant norms and patterns of many universities have not always met the social and academic needs of first-year students.

For some students, the separation phase means developing new friendships as well as changing their behaviours, and learning new bodies of knowledge, and employing new ways of thinking in an intellectual field or professional practice. While students who can adjust to their new environment can create a sense of belonging, it is during this phase that some students experience social alienation and personal challenges. Universities must ensure that they have clear transformative support structures and orientation programmes in place to ensure that this separation phase is not severely traumatic for first-year students.

Students' backgrounds and their income level are some of the social challenges that can affect their integration into university spaces as Camelia and Nastase (2018) have reminded

The \#FeesMustFall protests, beginning in 2015, and running into 2016, were based on the two central demands of free higher education and quality decolonised education. 
us. This was one of the challenges highlighted during the \#FeesMustFall protests. Students experience "incongruence" (Tinto, 1983, p. 50) when they feel that they do not belong to the social or academic sectors of the university. For many first-year students in South Africa, this is a common experience (Dison et al., 2019). Students also experience "isolation" (Tinto, 1983 , p. 50) when they are unable to form meaningful relationships or communicate effectively with people (such as peers or lecturers) at the university because of their social or financial background. This could lead to students being unable to access important information and this could lead, in turn, to their withdrawing voluntarily from tertiary studies. Students' income, particularly if it is low, is also a common factor leading to dropout (Lassibille \& Gómez, 2008; Ramrathan, 2013) but it can also affect feeling included or excluded at university. In the absence of sufficient funding, students could find themselves without safe accommodation and lacking food security.

During the separation phase, personal challenges may influence whether students feel included or excluded. Students who are enrolled at large universities can be at greater risk of isolation because of the wide physical spaces, complex administrative structure, diversity of the student body (Tinto, 1983), large student numbers (Jones et al., 2008), and universityspecific cultures and traditions (Kuh \& Love, 2000). Isolation can be further compounded by challenges relating to students' adaptability to or familiarity with university culture (Camelia $\&$ Nastase, 2018; Dison et al., 2019), with these leading to first-year students feeling that they do not belong to the social or academic sectors of the university (Tinto, 1983). These feelings of non-belonging can contribute to a sudden disequilibrium which could lead to students becoming reluctant to communicate with their lecturers and seek, instead, academic support from peer networks (Norodien-Fataar \& Daniels, 2016).

\section{Transition phase}

The transition phase is the period during which students are torn between the past (high school) and the present (university). According to Tinto (1983), during this phase, students must acquire the knowledge and skills needed to interact with members of a new group and find ways to adhere to the norms, values, and beliefs (Kuh \& Love, 2000) of the university. The transition stage is not always the same for each student, given their diverse lived experiences (Tinto, 1983) and the differences in their social capital. Therefore, universities cannot assume that the transition phase will be the same for all students and should be obliged to ensure that their diverse needs are accommodated. Furthermore, some students might find it challenging to understand the structural procedures of the university that tend to be far removed from those of school and this could lead to their dropping out. Furthermore, first-year students are more likely to drop out if they are unable to integrate sufficiently into the social life of the university to form social networks and manage social freedoms (Forbes \& Wickens, 2005; Mostert \& Pienaar, 2020).

The shift in the transition phase is not clearly sequenced so every student's goals, and these differ naturally among students, and their objectives contribute to making the transition successful (Tinto, 1983). It is during this stage that students encounter psycho-pedagogic challenges that include inconsistencies between the academic knowledge and skills that were 
prioritised at school and the expectations of university courses (Camelia \& Nastase, 2018; Dison et al., 2019; Ramrathan, 2013; Slonimsky \& Shalem, 2006). While almost all first-year students experience difficulties in adjusting to the academic literacy level required to function optimally at university (Brenner \& Shalem, 2010; Dison et al., 2019), this is of particular concern given the increasing number of students who are not academically prepared for the expectations of higher education enrolling at universities (Gabriel, 2008; Lassibille \& Gómez, 2008). Hence universities need to have a more transformative agenda as argued for by the \#FeesMustFall movement.

Universities expect students to adjust to the level of academic literacy required at university that is described as the gap between lecturers' expectations and students' ability to deliver expectations (Brenner \& Shalem, 2010; Mumba et al., 2002). This is problematic because school-leavers do not necessarily have access to academic discourses and literacy practices that will allow them to feel included at university. Furthermore, students' expectations of academic challenges as opposed to the actual challenges they encounter might be different. It is thus the responsibility of the university to minimise the impact that various knowledge gaps have on students' future learning. This would mean that first-year course curricula need to incorporate various academic reading and writing skills. If this were to be done, students would feel more included and, therefore, less excluded from academic programmes at university and their sense of being marginalised would at least begin to evaporate.

\section{Incorporation phase}

The final stage entails students' adjustment and involvement in the social and academic communities of the university. During this stage new interaction patterns are established with peers, lecturers, and administrative staff, resulting in students feeling more socially and academically involved at university. This does not mean that first-year students must adapt to the university's dominant culture to gain a sense of belonging since the dominant culture could be exclusionary in its refusal to acknowledge the social identities of all students. Therefore, universities should ensure that students have various options to socialise-even in sub-groups that share similar norms, values, and beliefs (Kuh \& Love, 2000, Tinto, 1983) to feel included at university. During this stage universities need to ensure that students start to feel more comfortable and included in the university environment because their diverse needs are being met. For this reason, it is important to understand students' expectations and experiences in their first few weeks at university.

\section{Theoretical perspective: Social and pedagogic inclusion}

The theoretical framework underpinning this study is social and pedagogic inclusion which is based on the premise that all people should be able to participate in activities as valued, respected, and contributing members of a learning community (Florian \& Black-Hawkins, 2011). There are five key aims (Freiler, 2001) that are linked to social inclusion and these include: (a) valued recognition and respect for individuals and groups; (b) opportunity for human development and for nurturing the talents and skills of students; (c) involvement and 
engagement in having the necessary support to be involved in decisions affecting oneself and one's community; (d) proximity in sharing physical and social spaces to provide opportunities for interactions and to reduce social distances between people; and (e) material well-being. We view the aims of this framework as overarching ideas that are best suited to explore the aspects that make first-year students feel included or excluded from university since the framework focuses on the social dimension of human interactions.

In our study, the first aim was linked to student development and to the acceptance of social identities within the university. We interpreted the second aim in relation to experiences that are associated with students' emotional and academic development at university. We linked the third aim to students' experiences of navigating the university structures and the fourth to students' experiences of social interactions at university. We viewed material well-being as being associated with participants' financial status.

Inclusive pedagogy focuses on raising the achievement of all and ensuring that those who are more vulnerable to being excluded or marginalised feel included (Englebrecht \& Green, 2018). For this to be achieved, institutions of higher learning have the responsibility to make various social and pedagogic changes to meet all students' needs rather than expecting the students to fit in with exclusionary structures and practices (Forslund Frykedal \& Hammer Chiriac, 2018; Makoelle, 2014). In South Africa there are various interpretations of inclusive pedagogy as Makoelle (2012) has noted. In this study, we define inclusive pedagogy as a teaching practice that encourages the full and meaningful participation of all students given the available learning opportunities.

We thus interpreted the social aims listed by Freiler (2001) to make links to accounts of pedagogic inclusionary and exclusionary experiences because we believe that social and pedagogic inclusion are not mutually exclusive. We used Freiler's (2001) aims of inclusion to guide our initial analysis of the data, and while we did not use them as specific categories when coding it, they did provide an organising framework for the categories that emerged from the data itself.

\section{Research methods}

We selected a phenomenological approach because the study aimed to "[describe] the meaning of the lived experiences of a phenomenon or concept for several individuals" (Fouché \& Schurink, 2011, p. 316). Since the study aimed to capture a snapshot of the research participants' expectations and experiences of inclusionary and exclusionary practices at university and the highly relative nature of such experiences, we agreed that a phenomenological approach was best suited. Given the number of research participants $(N=$ 322), we did not conduct the typically long interviews with participants that are usually associated with a phenomenological research design. Our research findings are based on participant responses from a much larger proportion of the research population, and this allows us to generalise our findings more widely. While we came to data analysis using Freiler's (2001) aims of inclusion to shape our view of what is relevant data and what is not, 
the eventual categories we used to code emerged from the data itself. In this way, we have been able to analyse it using relevant categories that describe adequately this data set.

We ensured reliability in this study by giving all the research participants the same set of questions to answer at the same time (in the first and sixth weeks of class). We ensured trustworthiness by dividing the data analysis between us thus requiring us to develop a sharp coding tool to ensure that coding was accurate and precise.

\section{Sampling and data collection}

Participants were selected from the 2020 first-year students registered to do a Bachelor of Education at an urban South African university. Like all students, they participate in an introductory programme orienting them broadly to the services, structures, and academic expectations of the university. Lecturers also introduce students to the expectations inherent in their specific courses. We obtained informed consent from these 322 first-year students to include their responses in this research. We were given permission to conduct this research by the University's ethics committee. We made participants aware that their involvement in this project was voluntary and that all identifying participant information would be kept confidential.

The research participants were asked to answer the following questions during their first week of lectures.

1. What do you think will make you feel included at university?

2. What do you think will make you feel excluded at university?

After six weeks, participants were invited to answer the following questions.

1. Which aspects have made you feel included into university life?

2. Which aspects have made you feel excluded from university life?

By asking participants what they expected to make them feel included and excluded and what actually made them feel included and excluded we uncovered their perception of the attributes and knowledge they need to succeed in the academy. The comparison of responses at two points in time reveal differences between anticipated and actual experiences of their transition.

\section{Data analysis}

Generally guided by the principles of inclusion (Freiler, 2001), we categorised the data according to the focus of the response. These various foci that included reference to academic, emotional, and social identities, financial issues, and the navigation of university structures and social interactions emerged in a grounded way from the data itself; through a process of immersion in the data, we pulled out the common foci of the responses (see Table 1). 
We soon realised that the data did not speak only to the areas in which participants felt included or excluded. A second level of refinement refocused the intention of the response to show that within a focus, there are different emphases on the various grounds for feeling included or excluded. We found Maton's (2014) distinction between epistemic relations and social relations useful. Epistemic relations refer to "relations between practices and their object" (Maton, 2016, p. 12). In this study, on the one hand, we understand this to mean the academic practices and university structures that students believe they need to master in order to succeed in higher education institutions. Social relations, on the other hand, refer to the "relations between practices and their subject" (Maton, 2016, p. 12). In the context of this study, we understand this to refer to the dispositions that students believe they need in order to achieve at university. Although all responses emphasised stronger social relations, they emphasised epistemic relations to different extents. For example, responses that had stronger epistemic relations valued knowing about academic practices, procedures, and structures, like, for example, knowing how to write academic essays. When responses had weaker epistemic relations their engagement with the academic practices and procedures of the academy were not the focus of their concern. In such cases, the responses were more concerned with their ways of being and belonging as being important for succeeding at university. We could, therefore, analytically distinguish differing emphases on the six categories of response.

Table 1

Table showing differing strengths of epistemic relations

\begin{tabular}{|c|c|c|c|}
\hline Focus of response & Basis of response & Indicator & Example \\
\hline \multirow[t]{2}{*}{ Academic } & $\begin{array}{l}\text { Epistemic relations are } \\
\text { more emphasised, with } \\
\text { stronger social } \\
\text { relations }\end{array}$ & $\begin{array}{l}\text { Response emphasises the } \\
\text { possession or lack of } \\
\text { knowledge about academic } \\
\text { practices, procedures, and } \\
\text { structures as important in } \\
\text { feeling included or excluded } \\
\text { in academic activities. }\end{array}$ & $\begin{array}{l}\text { "The way of doing things at } \\
\text { varsity, I feel like it will take time } \\
\text { for me to learn how to do things } \\
\text { (referencing, and all that stuff)." }\end{array}$ \\
\hline & $\begin{array}{l}\text { Epistemic relations are } \\
\text { less emphasised, with } \\
\text { stronger social } \\
\text { relations }\end{array}$ & $\begin{array}{l}\text { Response emphasises the } \\
\text { possession or lack of } \\
\text { personal dispositions or } \\
\text { interactions as important for } \\
\text { feeling included or excluded } \\
\text { in academic activities. }\end{array}$ & $\begin{array}{l}\text { "When I cope with university } \\
\text { work and get used to the norm of } \\
\text { the institution." }\end{array}$ \\
\hline \multirow[b]{2}{*}{ Emotional } & $\begin{array}{l}\text { Epistemic relations are } \\
\text { more emphasised, with } \\
\text { stronger social } \\
\text { relations }\end{array}$ & $\begin{array}{l}\text { Response emphasises the } \\
\text { possession or lack of } \\
\text { knowledge to feel } \\
\text { emotionally secure. }\end{array}$ & $\begin{array}{l}\text { "I will feel excluded when I face } \\
\text { a situation of humiliation and not } \\
\text { being briefed about how to cope } \\
\text { and what is expected of me as a } \\
\text { first-year student." }\end{array}$ \\
\hline & $\begin{array}{l}\text { Epistemic relations are } \\
\text { less emphasised, with } \\
\text { stronger social } \\
\text { relations }\end{array}$ & $\begin{array}{l}\text { Response emphasises the } \\
\text { possession or lack of ways of } \\
\text { being to feel emotionally } \\
\text { secure or insecure. }\end{array}$ & $\begin{array}{l}\text { "Having a sense of not belonging, } \\
\text { feeling like I am alone, and I } \\
\text { have no one to share my } \\
\text { academic experiences or even } \\
\text { academic stress with." }\end{array}$ \\
\hline
\end{tabular}




\begin{tabular}{|c|c|c|c|}
\hline \multirow{2}{*}{ Social identities } & $\begin{array}{l}\text { Epistemic relations are } \\
\text { more emphasised, with } \\
\text { stronger social } \\
\text { relations }\end{array}$ & $\begin{array}{l}\text { Response emphasises the } \\
\text { possession or lack of } \\
\text { knowledge to feel that they } \\
\text { are being treated fairly or } \\
\text { unfairly. }\end{array}$ & $\begin{array}{l}\text { "Other students know almost all } \\
\text { South African languages of } \\
\text { which I do not know." }\end{array}$ \\
\hline & $\begin{array}{l}\text { Epistemic relations are } \\
\text { less emphasised, with } \\
\text { stronger social } \\
\text { relations }\end{array}$ & $\begin{array}{l}\text { Response emphasises the } \\
\text { possession or lack of ways of } \\
\text { being to feel that they are } \\
\text { being treated fairly or } \\
\text { unfairly. }\end{array}$ & $\begin{array}{l}\text { "The background of which I } \\
\text { come from. Majority of the } \\
\text { student body are black South } \\
\text { Africans, yet I will be excluded } \\
\text { due to the fact that I have a } \\
\text { private schooling background." }\end{array}$ \\
\hline \multirow[b]{2}{*}{ Financial } & $\begin{array}{l}\text { Epistemic relations are } \\
\text { more emphasised, with } \\
\text { stronger social } \\
\text { relations }\end{array}$ & $\begin{array}{l}\text { Response emphasises the } \\
\text { possession or lack of } \\
\text { knowledge of how to cope } \\
\text { with student finances. }\end{array}$ & $\mathrm{n} / \mathrm{a}$ \\
\hline & $\begin{array}{l}\text { Epistemic relations are } \\
\text { less emphasised, with } \\
\text { stronger social } \\
\text { relations }\end{array}$ & $\begin{array}{l}\text { Response concerned being or } \\
\text { not being the right kind of } \\
\text { person with or without the } \\
\text { right kind of financial } \\
\text { security. }\end{array}$ & $\begin{array}{l}\text { "I feel excluded since I have to } \\
\text { travel from home to university } \\
\text { every day. Traveling } \\
\text { inconveniences me since I use } \\
\text { public transport, along the way I } \\
\text { encounter discrepancies since } \\
\text { public transport is not reliable } \\
\text { and I arrive late for my classes." }\end{array}$ \\
\hline \multirow{2}{*}{$\begin{array}{l}\text { Navigation of } \\
\text { university structures }\end{array}$} & $\begin{array}{l}\text { Epistemic relations are } \\
\text { more emphasised, with } \\
\text { stronger social } \\
\text { relations }\end{array}$ & $\begin{array}{l}\text { Response emphasises the } \\
\text { possession or lack of } \\
\text { knowledge in order to } \\
\text { navigate or not navigate } \\
\text { structural logistics. }\end{array}$ & $\begin{array}{l}\text { "I am not familiar with my } \\
\text { schoolwork being typed using a } \\
\text { personal computer." }\end{array}$ \\
\hline & $\begin{array}{l}\text { Epistemic relations are } \\
\text { less emphasised, with } \\
\text { stronger social } \\
\text { relations }\end{array}$ & $\begin{array}{l}\text { Response emphasises the } \\
\text { possession or lack of ways of } \\
\text { being in order to navigate or } \\
\text { not navigate structural } \\
\text { logistics. }\end{array}$ & $\begin{array}{l}\text { "Being able to access } \\
\text { information, participating and } \\
\text { attending." }\end{array}$ \\
\hline \multirow{2}{*}{ Social interactions } & $\begin{array}{l}\text { Epistemic relations are } \\
\text { more emphasised, with } \\
\text { stronger social } \\
\text { relations }\end{array}$ & $\begin{array}{l}\text { Response emphasises the } \\
\text { possession or lack of } \\
\text { knowledge in order to feel } \\
\text { included or excluded in } \\
\text { social activities. }\end{array}$ & $\begin{array}{l}\text { "I felt included when a lecturer } \\
\text { asks questions and ensures that I } \\
\text { understand." }\end{array}$ \\
\hline & $\begin{array}{l}\text { Epistemic relations are } \\
\text { less emphasised, with } \\
\text { stronger social } \\
\text { relations }\end{array}$ & $\begin{array}{l}\text { Response emphasises the } \\
\text { possession or lack of ways of } \\
\text { being in order to feel } \\
\text { included or excluded in } \\
\text { social activities. }\end{array}$ & $\begin{array}{l}\text { "Being treated like I know } \\
\text { everything and not being asked } \\
\text { my opinions." }\end{array}$ \\
\hline None & & \multicolumn{2}{|l|}{ "Nothing up to so far." } \\
\hline
\end{tabular}

We began the coding process by developing a few categories and testing them separately on the same sample of the data. We then compared our coding to ensure congruence between our interpretations of the data. After a few rounds of this procedure, by gradually sharpening the analysis tool to accommodate the themes in the data, we each coded half of the full dataset. We generated the quantities of each code combination in the initial and follow-up datasets, thereby making trends in participants' perceptions of inclusion and exclusion over time 
visible. Data and shifts which accounted for $5 \%$ to $10 \%$ of the findings were considered noteworthy, $10 \%$ to $15 \%$ were considered striking, $16 \%$ to $29 \%$ were considered substantial, $30 \%$ to $39 \%$ were considered remarkable, and over $40 \%$ were considered eminent.

\section{Findings}

The findings discussed below are arranged by focus area. Within each focus area, we begin by discussing the overall trends within the data. Then, we discuss the data from the initial dataset which asked participants "What will make you feel included/excluded at university?" Thereafter, we discuss the shifts that occurred during the six weeks of the study as evidenced in the follow-up dataset that asked participants, "Which aspects have made you feel included/excluded at university?"

The discussion of the findings refer to the summary in Table 2.

\section{Table 2}

Summary of findings

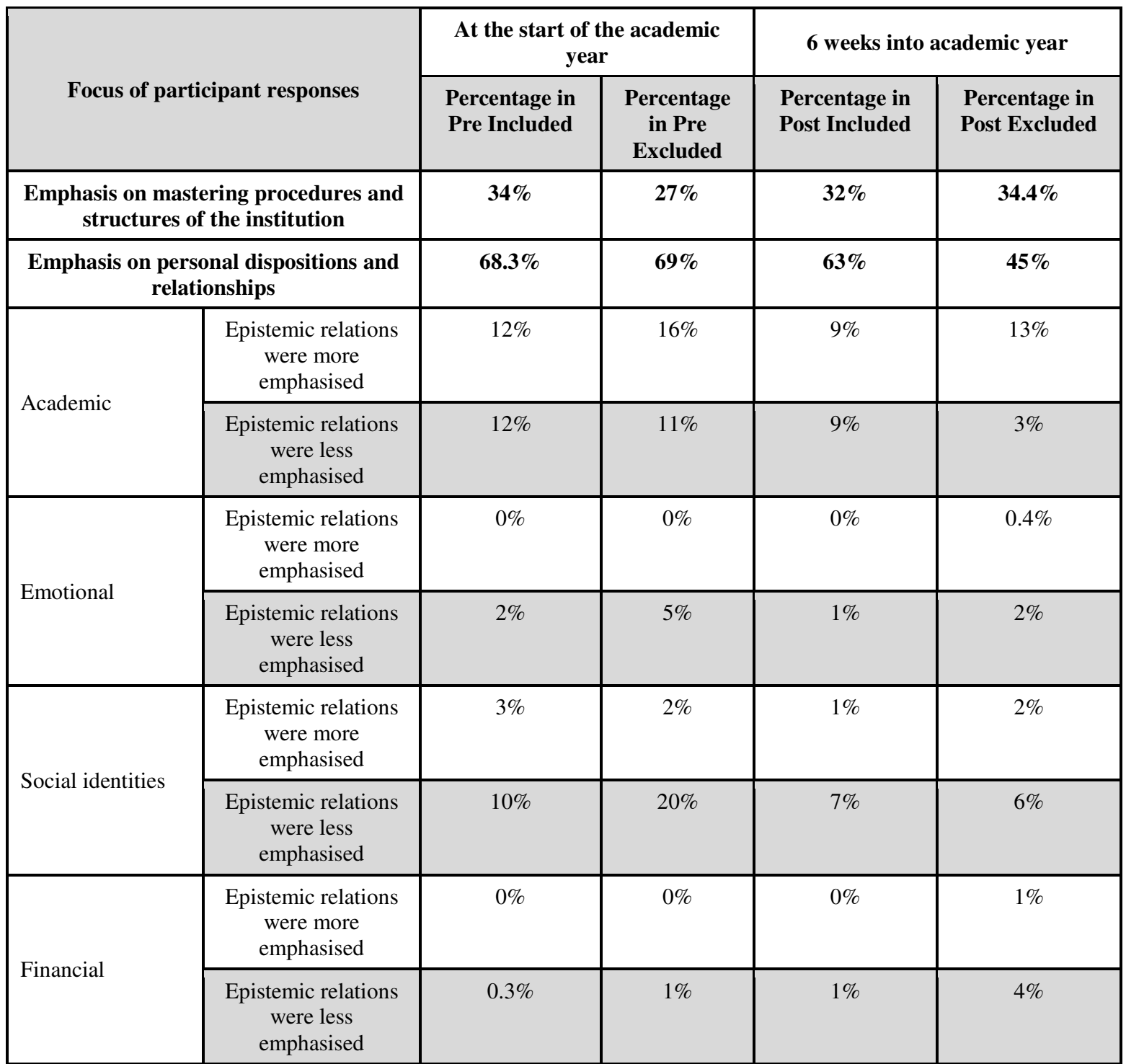




\begin{tabular}{|c|c|c|c|c|c|}
\hline \multirow{2}{*}{$\begin{array}{l}\text { Navigation of } \\
\text { university } \\
\text { structures }\end{array}$} & $\begin{array}{c}\text { Epistemic relations } \\
\text { were more } \\
\text { emphasised }\end{array}$ & $8 \%$ & $6 \%$ & $9 \%$ & $11 \%$ \\
\hline & $\begin{array}{c}\text { Epistemic relations } \\
\text { were less } \\
\text { emphasised }\end{array}$ & $3 \%$ & $1 \%$ & $5 \%$ & $5 \%$ \\
\hline \multirow{2}{*}{ Social interactions } & $\begin{array}{c}\text { Epistemic relations } \\
\text { were more } \\
\text { emphasised }\end{array}$ & $11 \%$ & $3 \%$ & $13 \%$ & $7 \%$ \\
\hline & $\begin{array}{c}\text { Epistemic relations } \\
\text { were less } \\
\text { emphasised }\end{array}$ & $41 \%$ & $31 \%$ & $40 \%$ & $25 \%$ \\
\hline \multicolumn{2}{|l|}{ None } & $0 \%$ & $1 \%$ & $3 \%$ & $19 \%$ \\
\hline \multicolumn{2}{|l|}{ Unable to code } & $0 \%$ & $0 \%$ & $1 \%$ & $1 \%$ \\
\hline
\end{tabular}

To streamline the presentation and discussion of findings, we have chosen not to present categories that had percentages lower than $5 \%$, so we will not elaborate much on the emotional and financial categories. We assume that students are emotionally mature and ready to be at university or that they simply do not regard emotional aspects as important ones in their transition to university. We find it very interesting that, contrary to the findings of Camelia and Nastase (2018) and Ramrathran (2013), research participants in this study did not express much concern about inclusion or exclusion in relation to their finances since we consider students who fall into a low-income category as being at risk of being excluded from many social and academic aspects of the academy. Our finding is somewhat counterintuitive considering the focus of student protests and struggles of recent years that had a heavy focus on student finances (such as the \#FeesMustFall movement). It is possible that these participants have access to student funding and hence this is not of great concern in our dataset.

For the participants in this study, "fitting in" in relation to social interactions dominated their concern about inclusion on entry into the institution. Most of the participants in this study seem to associate inclusion, and what is valued by the academy, with their social interactions. They seem to be more focused on establishing social networks than on mastering academic practices. An eminent preoccupation with social belonging may render actors unaware of the inclusionary and exclusionary power of academic and financial belonging and other aspects of university life. Indeed, after six weeks on campus, there was a striking decrease in participants' concerns about having or not having particular personal dispositions as inclusionary or exclusionary factors. There was also a slight increase in participants' concerns about mastery of knowledge, procedures, and structures in order to be included after their first six weeks on campus. An example of this is best indicated in this student's response in its expressing an initial concern about being socially excluded because of being an "introvert" who finds "it difficult ... to start a conversation." However, after six weeks, the same student indicated that "the use of computers which I am not familiar with" led to feelings of exclusion because of being unequipped to use the technology because "at school we didn't have computer labs where you can acquire some of the skills of using a computer."

2 All participant transcripts are verbatim and have been edited only slightly in the interests of coherence. 
This participant experienced exclusion in relation to the university structures that require students to type assignments.

\section{Social interactions as key points of inclusion or exclusion}

The findings of this study indicate that social interactions were expected to be, as well as experienced as, a valued part of feeling included in the university. Being part of a social group and knowing which groups to join came up when participants identified what they thought would (or did) make them feel included or excluded at university.

The dataset saw an eminent focus on establishing a network of peers when participants were describing their expectations of social inclusion if they were able to "[build] friendships," and “... [participate] in student ... sports and clubs and [attend] sports days.” Participants expected to feel included if they "[knew] people who [would] help [them] when [they] feel lost or confused." Knowledge about the structures and workings of the institution and procedures for getting information was expected to, or did, make them feel included at university. Furthermore, a remarkable number of participants expected to feel marginalised if they were excluded because they did not "fit in." For example, they feared that they would feel excluded if they struggled to "transition or fit in properly," or were unable to participate in friendship groups, clubs, and other social groups.

A noteworthy number of participants reported that, after the six-week period, they experienced social exclusion because, for example, "the language barriers make it quite difficult to make friends ..." or because they found it difficult to make friends because of the cosmopolitan student body. These findings are in keeping with those of Gerdes and Mallinckrodt's (1994) study that showed that social adjustment was a major factor in student success at university. Following Tinto's (1983) projection, students felt isolated if they had not yet formed meaningful relationships.

\section{Academic success as determining inclusion and exclusion}

Participants also came to recognise that academic practices, such as academic writing, referencing, and knowing where to seek help with academic writing and reading, is valued as an important part of success in the academy. They cited academic concerns as being points of inclusion and exclusion in both their predictions about and their experiences of feeling included at the university. A striking number of participants expected to feel included if they succeed academically in the university space, which echoes the findings of Gerdes and Mallinckrodt's (1994) study. An interesting finding is that an equal number of participants' responses emphasised the mastery of knowledge as well as the personal dispositions they regarded as important for expectations of inclusion in relation to academic issues.

In the initial dataset, participants expected to be included if they "actually [understood] all the syllabus of all [their] course[s]" and imagined that if they had a good grasp of the content that they were taught in lectures, they would feel included. Responses from participants reported that they would feel included if they were recognised for their academic achievement and 
fitted into the group of "one of those best students." A substantial number of participants' responses expressed what Tinto (1983, p. 50) calls "incongruence." Their responses included statements like " $[\mathrm{w}]$ hen the lecturer moves fast, being lost/left behind, not understanding the lectures and having a lot of work from different courses." A noteworthy number of responses emphasised the personal dispositions associated with academic success when they reported that they expected to feel excluded if they were unable to participate in academic interactions, or they would "[not be] recognized for the hard work and effort that [they] enforce to make sure that [they] perform greatly."

We observed a noteworthy decrease in emphasis on personal dispositions when participants were reporting their experiences of exclusion after six weeks. For example, one participant predicted that "being ignored especially by the lecturer if I ask for help where I don't understand" led to feelings of academic exclusion. After six weeks, however, the same student reported experiencing social exclusion when "communicating with students [who speak] other languages." Participants experienced exclusion when they felt unable to adapt to the new environment, and this resulted in feelings of isolation and marginalisation (see Bean \& Eaton, 2000; Tinto, 1983) when they saw "other students looking like they [are] coping with certain courses, [that they] have no clue about," which made them "feel stupid," and "[lose] all sense of belonging."

\section{Social identities and feeling accepted}

A striking number of the participants said that they expected that experiences of equity would be a consequence of feeling included at university. Following Dison et al. (2019) not only did participants expect to feel included if they were treated fairly, but they also expressed fears of feeling isolated because they were not seen to be valued in the university's society (see Dison et al., 2019). At the beginning of the six weeks, participants were concerned about "being treated different because of the colour of [their] skin," and "having their opinion valued by others." A substantial percentage of the responses indicated that participants expected to feel excluded if they were treated unfairly if, for example, "[lecturers] will be focusing on excelling students only," or because "food sold at the canteen does not cater for all ethnic groups."

After six weeks, there was a noteworthy decrease in experienced inclusion because the participants were being treated fairly. Participants who did experience a feeling of inclusion because of this tended to emphasise particular ways of being and dispositions in their responses, reporting that "in lectures and tutorials we are all treated equally regardless of our different backgrounds." There was a substantial reduction of students who expressed fear that they would be excluded on the grounds of their social identity. The trends in our dataset indicate that participants, overall, overestimated the role that equity would play as an inclusionary factor at university. For example, a participant predicted that they would feel included "when lecturers treat me the same as other [students]" but after six weeks, what made this participant feel included was "receiving all the work at the correct time as other students." This participant, then, shifted their focus from having the right kind of dispositions to be treated equally to knowing how to navigate the university's structures. Whether this was 
because the participant had established a network of peers with similar social identity or from similar backgrounds or they adapted to fit in is unclear, but the participants in this study seemed to experience inclusion or exclusion because they were treated fairly much less often than they expected to be.

\section{Navigation of university structures}

When participants spoke about feeling included or excluded in relation to having access to knowledge about campus structures and systems, they tended to focus more on knowledge than on their personal dispositions. They, therefore, acknowledged that a part of feeling included in the institution was knowing where to go and what to do in and around campus. A noteworthy number of participants expected to feel included or excluded because they did or did not know what was happening in and around the campus. Initially, they mentioned anxieties about knowing "the protocols and knowing exactly what [they were] going to learn about." Accordingly, they expected to feel excluded if they did not know what was happening on campus, leading to their "feeling lost and not knowing where [they are] or where [they are] supposed to be."

There was a noteworthy increase in the exclusionary experiences of participants because they felt that they did not know or understand the university's procedures and structures. Participants reported feeling excluded because they had difficulties with using technology to prepare and submit their work and felt excluded when they found out about changes to their lectures or assignments at the last minute from others, leading them to feel the isolation that Tinto (1983) says accompanies the transition from school to tertiary education. For one participant, being excluded would mean being "discriminated against due to certain differences that [they] might have that other people do not have nor understand," whereas after six weeks, this participant experienced exclusion in relation to the mastery of knowledge when "navigating [their] way through these huge buildings with weird names."

\section{'None'}

A substantial number of participants felt that they had not experienced exclusion in their first six weeks of university. One participant said that "there are some moments when I feel excluded by fellow students, but I choose not to allow these moments to affect my overall positive experience of university so far." While it is not clear why so many participants have had this experience, some possible hypotheses include a belief that students are approaching their new role with a maturity that promotes focus and determination within the university space. Perhaps the participants have a sense that they can succeed because they were able to achieve access to the university. It could also be that the university's structures to support transition have helped these participants. Other participants claimed that their motivations come from within, and so "for [them] SOLITUDE IS BLISS," or "only I can allow myself to feel excluded from anything. How I continue in my experience at varsity is not determined by other people's experiences and connections." A final hypothesis, according to the work of Alamuddin and Bender (2018), is that the first-year orientation programmes have enabled students to find ways to be included in the university space. 


\section{Discussion}

The analysis of our data suggests that first-year students' expectations of what it would be like at university shifted after six weeks. This study has five main findings. First, it would seem that this cohort of first-year students' biggest anxiety when starting university was social interactions and experiences, and therefore they predicted initially that social interactions would be a key point of inclusion and exclusion at university. For some students, adjusting was seen primarily as establishing a social network, with less initial concern for understanding the structures and expectations about knowledge practices. Their responses indicate that, for them, when they fit in socially, they feel that they are included at university. It would seem, then, that either the knowledge practices of the academy are not yet visible to students when they enter university, or that participants are holding firm to that perception of being "bright and hardworking" enough to belong to the institution as advertised on the university's website (University of the Witwatersrand, Johannesburg, 2020, n.p.).

Second, participants in this study place less value on financial support as the overarching factor for feeling included or excluded at university. There were some participants in this study who did cite financial issues as exclusionary factors, but they were few and far between. This may not be the case with a different set of students at this or another university. Financial and food security is of massive concern in South African universities and in the country as a whole and must be acknowledged as a powerful exclusionary factor for many South African students.

Third, participants reported that academic success and achievement would make them feel included at university and failure would make them feel excluded. This indicates that participants consider knowing the procedures, structures, and processes is an important component of feeling included in the academy. Furthermore, after six weeks, participants seemed to realise the importance of academic conventions and the knowledge of university structures if they were to succeed. Fourth, participants' responses intimated that they feared that they might not be treated fairly because of some personal trait, but after six weeks at university the focus on this aspect decreased notably.

Last, participants' responses about their struggles with the use of technology and how logistical navigation of the university's systems hampered their academic success shows that they valued knowledge of the university's processes including its technological concerns as part of being included at university. When they were unable to navigate logistical and technological aspects after six weeks at university, they felt excluded. Despite these findings, a substantial number of participants reported no experiences of exclusion after six weeks. Indeed, participants tended to emphasise personal dispositions in their responses until they were asked what made them feel excluded after six weeks. Their experiences of exclusion foregrounded mastery of knowledge, procedures, and processes marginally more than their expectations of inclusion and exclusion, as well as their experiences of inclusion. We postulate that this could mean that the knowledge practices of the academy are not yet visible 
to students, or that the students underestimated the inclusionary or exclusionary power of knowledge at university.

What these findings suggest is that first-year students have a limited frame of reference with regard to their expectations of what inclusion in the academy entails. This has been evidenced by their locating social support and participation as a key aspect of feeling included and or excluded as well as succeeding at university. They seem to be highly influenced by media depictions of university spaces as predominantly social spaces. As such, the academic, financial, and logistical demands of being at university have not been a focal aspect of feeling included and/or excluded at university for these participants.

\section{Conclusion}

This qualitative study explored the perceptions of inclusion and exclusion of first-year students at a South African university. It compared their expectations and lived experiences of inclusion and exclusion. Within each of the focus categories which emerged from the data, we distinguished two bases for the response: responses either emphasised mastery of knowledge, processes, and structures to feel included/excluded or responses emphasised personal dispositions to feel included/excluded. The findings of this study are perhaps best captured in this quote from the data, "Honestly, I haven't had the fun that is portrayed at university from afar." The experiences of participants after the first six weeks of university are quite different from their expectations of university life. The findings indicate that participants experienced mastery of knowledge, procedures, and structures of the institution as a point of exclusion almost $8 \%$ more than they expected. The participants also experienced personal disposition and relationships to be a point of exclusion $24 \%$ less than they expected them to be.

This paper therefore contributes to the field of knowledge on transitioning from high school to university by noting that first-year students place much more focus on the social aspects of university life. The findings also have implications for how universities conceptualise and implement the move to online learning which is often viewed as the solution to the provision of higher education. We encourage universities to examine their orientation programmes critically to note what kinds of expectations and experiences are being foregrounded and promoted to first-year students.

A limitation of this study is that our data was gathered from one cohort of first-year students and, as such, we do not claim that our findings can be generalised to all first-year students. We recommend that more research be done at other universities on first-year students' expectations and experiences at university that would lead them to experiencing inclusion and exclusion. 


\section{References}

Alamuddin, R., \& Bender, M. (2018). First-year student support: Supporting high-achieving first-year students at public two-year institutions. Jack Kent Cooke Foundation: Ithaka $\mathrm{S}+\mathrm{R}$.

Araque, F., Roldan, C., \& Salguero, A. (2009). Factors influencing university dropout rates. Computers \& Education, 53, 563-574.

Bean, J. P., \& Eaton, S. B. (2000). A psychological model of college student perception. In J. M. Braxton (Ed.), Reworking the student departure puzzle (pp. 48-61). Vanderbilt University Press.

Brenner, E., \& Shalem, Y. (2010). Immediate response to mediated learning: The use of technology for continuous assessment in higher education. In Council on Higher Education, Teaching and Learning: Beyond formal access - Assessment through the looking glass (pp. 65-80). Council on Higher Education.

Camelia, S., \& Nastase, E. (2018). University dropout: Causes and solutions. Journal of Economic Studies, 10(4), 2-4.

Case, J. M., Marshall, D., McKenna, S., \& Disaapele, M. (2018). Going to university: The influence of higher education on the lives of young South Africans. African Minds.

Dias, D., \& Só, M. J. (2014). The impact of the transition to HE: Emotional feelings and sensations. European Journal of Education, 49, 291-303.

Dison, L., Shalem, Y., \& Langsford, D. (2019). Resourcefulness matters: Student patterns for coping with structural and academic challenges. South African Journal of Higher Education, 33(4), 76-93.

Engelbrecht, P., \& Green, L. (2018). Responding to the challenges of inclusive education in Southern Africa (2nd ed.). Van Schaik.

Florian, L., \& Black-Hawkins, K. (2011). Exploring inclusive pedagogy. British Educational Research Journal, 37(5), 813-828.

Forbes, A., \& Wickens, E. (2005). A good social life helps students to stay the course. Times High Education Supplement, 1676, 58-63.

Forslund Frykedal, K., \& Hammar Chiriac, E. (2018). Student collaboration in group work: Inclusion as participation. International Journal of Disability, Development and Education, 65(2), 183-198. 
Fouché, C. B., \& Schurink, W. (2011). Qualitative research designs. In A. S. De Vos, H. Strydom, C. B. Fouché \& C. S. Delport, Research at grass roots: For the social sciences and human services profession (4th ed.), pp. 307-327). Van Schaik.

Freiler, C. (2001). Toward a vision of social inclusion for all children. Laidlaw.

Gabriel, K. (2008). Teaching unprepared students: Strategies for promoting success and retention in higher education. Stylus Publishing LLC.

Gerdes, H., \& Mallinckrodt, B. (1994). Emotional, social, and academic adjustment of college students: A longitudinal study of retention. Journal of Counselling and Development ProQuest Central, 72(3), 281-288.

Jones, B., Coetzee, G., Baily, T., \& Wickham, S. (2008). Factors that facilitate success for disadvantaged higher education students. Rural Education Access Programme (REAP).

http://www.reap.org.za/pieces/reports/pdf/tracking_reports/2008_June_factors_that_f acilitate_success.pdf

Kuh, G. D., \& Love, P. G. (2000). A cultural perspective on student departure. In J. Braxton (Ed.), Rethinking the departure puzzle: New theory and research on college student retention. Vanderbilt University Press.

Kwai, C. (2009). Model of international students' persistence: Factors influencing retention of international undergraduate students at public state-wide four year university systems (Unpublished doctoral dissertation). University of Minnesota.

Lassibille, G., \& Gomez, L. (2008). Why do higher education students drop out? Evidence from Spain. Education Economics, 16(1), 89-105.

Letseka, M., Cosser, M., Breier, M., \& Visser, M. (2010). Student retention and graduate destination: Higher education and labour market access and success. Human Sciences Research Council Press.

Makoelle, T. M. (2012). The state of inclusive pedagogy in South Africa: A literature review. Journal of Sociology and Social Anthropology, 3(2), 93-102.

Makoelle, T. M. (2014). Changing teacher beliefs and attitudes towards inclusion in South Africa: Lessons from collaborative action research. Journal of Social Sciences, 38(2), 125-134.

Maton, K. (2014). Seeing knowledge and knowers: Social realism and Legitimation Code Theory. In Knowledge and knowers: Towards a realist sociology of knowledge (pp. 1-22). Routledge. 
Maton, K. (2016). Building knowledge about knowledge-building. In K. Maton, S. Hood \& S. Shay (Eds.), Knowledge-building: Educational studies in Legitimation Code Theory (pp. 1-23). Routledge.

Morrow, W. (1992). A picture holds us captive. In W. Morrow, Learning to teach in South Africa (pp. 37-50). Human Sciences Research Council Press.

Mostert, K., \& Pienaar, J. (2020). The moderating effect of social support on the relationship between burnout, intention to drop out, and satisfaction with studies of first-year university students. Journal of Psychology in Africa, 30(3), 197-202.

Mumba, F. K., Rollnick, M., \& White, M. (2002). How wide is the gap between high school and first-year chemistry at the University of the Witwatersrand? South African Journal of Higher Education, 16(3), 148-156.

Norodien-Fataar, N. \& Daniels, D. (2016). Exploring the educational engagement practices of disadvantaged students at a South African university. Alternation, 23(1), 90-112.

Ramrathan, L. (2013). Towards a conceptual framework for understanding student dropout from HEIs. South African Journal of Higher Education, 27(1), 209-220.

Slonimsky, L., \& Shalem, Y. (2006). Pedagogic responsiveness for academic depth. Journal of Education, 40, 35-58.

Tinto, V. (1983). Leaving College: Rethinking the causes and sures of student attrition (2nd ed.). University of Chicago Press.

Underhill, J., \& McDonald, J. (2010). Collaborative tutor development: Enabling a transformative paradigm in a South African university. Mentoring \& Tutoring: Partnership in Learning, 18(2), 91-106.

University of the Witwatersrand, Johannesburg. (2020, April 26). Undergraduate study at Wits. https://www.wits.ac.za/undergraduate/

Vincent, L., \& Hlatswayo, M. (2018). Ties that bind: The role played by social capital in black working class first-generation South African students' negotiation of university life. South African Journal of Higher Education, 32(3), 118-138. 